\title{
特集「中国乾燥地における緑化技術と光の将来」 $\mathrm{N}$
}

\section{中国の砂漠化防止に関する歴史および現在}

\section{王 林和 ${ }^{1)} \cdot$ 三木直子 ${ }^{2)} \cdot$ 李 $\quad$ 玉霊 ${ }^{3)} \cdot$ 楊 霊麗 ${ }^{2)} \cdot$ 吉川 賢 ${ }^{2)}$}

1) 中国内蒙古農業大学林学院 - 内蒙古自治区科学技術協会 Forestry College, Inner Mongolia Agricultural University, China - Inner Mongolia Autonomous Region Association for Science and Technology, China

2) 岡山大学大学院環境学研究科 Graduate School of Environmental Science, Okayama University, Japan

3) 中国河北農業大学林学院 Forestry College, Agricultural University of Hebei, China

\section{1. 砂漠化防止の歴史}

1.1 砂漠化の発生と進行

紀元前 200 年頃 , 漢の武帝が張騫を中国の西域に派遣し て, 乾燥した荒漠地で畑や用水路を建設する農業開発をさせ た。炎の結果, シルクロードに沿った樓蘭, 且末, 精絶, 若 羌 , 葉城 (叶城) などで灌溉農業が発達した。

敦煌城から南西へ約 $70 \mathrm{~km}$ のところに小さなオアシス一 南湖才アシスがある。唐の時代はここに寿昌県か設けられ， 大小の用水路 (令狐渠) で灌溉が行われていた。关の広さは ちょうど現在のオアシスと一致する。しかし, 敦煌文献によ ると, 当時の寿昌の才アシスは寿昌城を中心に, 南北 10 $\mathrm{km}$, 東西 $17.5 \mathrm{~km}$ で, 兴の面積は約 $120 \mathrm{~km}^{2}$ と, 現在より $5 \mathrm{~km}^{2}$ ほど広いものであっだ”。唐代にオアシスが縮小した のは環境変動を含めたいくつかの要因によるものと考えられ るが, 現在は再び灌溉施設の建設による農業開発が進み, 往 事を超える広がりを見せている(約 $\left.130 \mathrm{~km}^{2}\right)^{2}$ 。

河西回廊にはこれまで何度か乾燥期と湿潤期があつたが， 基本的に乾燥気候に属する。产のため ““流砂”とか”砂領” といった言葉が文献に多く記されている4)。

唐 , 宋時代の敦煌オアシスは, 西は砂州城の西 $12.5 \mathrm{~km}$ の馬圈口堰 , 南は砂州城の南 $5 \mathrm{~km}$ の鳴砂山山麓の神農渠, 東南は砂州城の東 $20 \mathrm{~km}$ の外の官渠であった。つまり唐， 宋代に敦煌オアシスは現在とほぼ同じ規模に達していたが， 兴の後の開発によって北部ではかなり範囲が広がっている。 技術の進歩による地下水利用が進んだためであるが , 水資源 には限界があり，オアシスの拡大に伴う生態環境の破壊が進 んでいる。

内蒙古自治区東部の科爾沁 [ホルチン] 砂地は, 現在高さ 3〜8 m の新月形の砂丘が並び, 農業生産はわずかに行われ ているに過ぎない。しかし，乥んな中で見つかった陽関遺跡 には陶片や鉄器あるいは古銭幣などが出土し, 昔は多くの 人々が生活していたことを伺わせている5
治区中央部の毛烏素砂地にも多くの唐代や漢代の遺跡 (漢代 は統万城, 奢延, 高望, 唐代は宥洲, 大石砭, 古城界) が 残っている。従って, 現在は砂漠や砂地になってしまってい るこうした地域の中には, 古くから人々か生活し，光のため に環境か破壊されて砂漠化したところが少なくない。

1.2 砂漠化の進行と現状

1.2.1 中国固有の砂漠

中国の砂漠や砂地はおもに第四紀に形成されたものである が, 光の後 300 万年の時を経て, 現在の砂漠や砂地となっ た。特に更新世中・晚期から完新世前・晚期に砂漠の拡大が 起こった (表-1 $)^{10)}$ 。樣々な資料によって, 更新世の前期か ら中期には, 塔里木 [タリム] 盆地のかなりの範囲がすでに 砂丘で覆われていたことか明らかとなっている。毛烏素砂地 においても更新世中期の風砂の堆積が見つかっている。更新 世晚期から完新世前期は地球規模で乾燥・寒冷化し, 海洋の 面積も大幅に減少したため, 中国の北部の地域は益々内陸的 な乾燥気候となり, 多くの湖や川が干上がってしまった。砂 質で乾燥している塔里木 [タリム] 盆地や準噶爾 [ジュンガ ル] 盆地（現在の塔克拉瑪干 [タクラマカン] 砂漠 , 古爾班

表-1 中国の砂漠と炎の面積

\begin{tabular}{lc}
\hline 砂漠名称 & 面積 $\left(\mathrm{km}^{2}\right)$ \\
\hline 塔克拉瑪干 [タクラマカン] 砂漠 & 337,600 \\
\hline 古爾班通古特 [グルバンツングート] & 砂漠 \\
\hline 庫姆塔格 [クムタグ] 砂漠 & 48,800 \\
\hline 柴達木 [ツァイダム] 盆地砂漠 & 22,800 \\
\hline 巴丹吉林 [バダインジャラン] 砂漠 & 34,900 \\
\hline 騰格里 [テンゲル] 砂漠 & 44,300 \\
\hline 烏蘭布和 [ウランブハ] 砂漠 & 42,700 \\
\hline 庫布斉 [クブチ] 砂漠 & 9,900 \\
\hline
\end{tabular}


通古特 [グルバンツングート] 砂漠), 祁連山の北 (現在の 巴丹吉林 [バダインジャラン] 砂漠, 騰格里 [テンゲル] 砂 漠)，賀蘭山の周辺 (現在の庫布斉 [クブチ] 砂漠地域)，鄂 爾多斯 [オルドス] 高原 (現在の毛鳥素砂地), 内蒙古高原 の南東部 (現在の渾善達克 [フンシャンダク] 砂地)，西遼 河流域 (現在の科爾沁 [ホルチン] 砂地)，および呼倫貝爾 [フルンバイル] 高原 (現在の呼倫貝爾 [フルンバイル] 砂 地) 等の地域はこの時期に砂漠化した。

また，毛烏素砂地や科爾沁 [ホルチン] 砂地での ${ }^{14} \mathrm{C} の$ 安 定同位体を用いた調査によると，弚れらの砂地は今からおよ 光 1500 3000 年前から急に拡大し始めたことが明らかと なっており 最近でも砂漠の拡大傾向は続いているといえる。

\subsection{2 中国における砂漠化土地}

元中国科学院蘭州砂漠研究所の朱震達所長の報告 ${ }^{11}$ による と，中国で砂漠化の危険がある土地の総面積はおよ光 33.4 万 $\mathrm{km}^{2}$ で, 光のほとんどが乾燥, 半乾燥地域である。すで に砂漠化した土地は約 17.6 万 $\mathrm{km}^{2}$ で, 残りの約 15.8 万 $\mathrm{km}^{2}$ は潜在的に砂漠化の危険がある土地である (表-2, 表-3)。 ぞのほか, チベットの雅魯藏布江 [ツァンポ川] の流域の低 地にも砂漠化土地か広がっている。

砂漠化の速度は 1950 60 年代は年平均 $1,560 \mathrm{~km}^{2}$ であつ たが, 1980 年代には年平均 $2,100 \mathrm{~km}^{2}, 1990$ 年代初めは年 平均 $2,460 \mathrm{~km}^{2}$ に増加した。国家林業局の周生賢局長は 2002 年 6 月 17 日, 砂漠化防止についての全国会議に出席

表-2 中国の砂漠化土地の分布

\begin{tabular}{|c|c|c|c|c|}
\hline 地 区 & $\begin{array}{c}\text { 総面積 } \\
\left(\mathrm{km}^{2}\right)\end{array}$ & $\begin{array}{c}\text { 砂漠化が進行 } \\
\text { している土地 } \\
\left(\mathrm{km}^{2}\right)\end{array}$ & $\begin{array}{l}\text { 砂漠化が著し } \\
\text { く進行してい } \\
\text { る土地 }\left(\mathrm{km}^{2}\right)\end{array}$ & $\begin{array}{l}\text { 砂漠化が最も } \\
\text { 進行している } \\
\text { 土地 } \quad\left(\mathrm{km}^{2}\right)\end{array}$ \\
\hline 呼倫貝爾 [ホロンバイル] & 3,799 & 3,481 & 275 & 43 \\
\hline 嫩江下流 & 3,564 & 3,286 & 278 & \\
\hline 吉林省の西部 & 3,374 & 3,225 & 149 & \\
\hline 大興安嶺の東側 (興安盟) & 2,335 & 2,275 & 60 & \\
\hline 科爾沁 [ホルチン] (通遼市) & 21,567 & 16,587 & 3,805 & 1,175 \\
\hline 遼寧省の西北部 & 1,200 & 1,088 & 112 & \\
\hline 西拉木倫 [シラムレン] 河上游 (赤峰市) & 7,475 & 3,975 & 1,875 & 1,625 \\
\hline 囲場 , 豊寧の北部 & 1,164 & 782 & 382 & \\
\hline 張家口以北坝上 & 5,965 & 5,917 & 48 & \\
\hline 錫林郭勒 [シリンゴール] および察哈爾 [チャハル] 草原 & 16,862 & 8,587 & 7,200 & 1,075 \\
\hline 後山地区 (烏蘭察布 [ウランチャブ] 盟) & 3,867 & 3,837 & 30 & \\
\hline 前山地区 (烏蘭察布 [ウランチャブ］盟) & 784 & 256 & 320 & 208 \\
\hline 山西省の西北部 & 52 & 52 & & \\
\hline 陝西省の北部 & 21,686 & 8,912 & 4,590 & 8,184 \\
\hline 鄂爾多斯［オルドス] & 22,320 & 8,088 & 5,384 & 8,848 \\
\hline 後套および烏蘭布和 [ウランブハ] 北部 & 2,432 & 512 & 912 & 1,008 \\
\hline 狼山以北 & 2,174 & 414 & 1,424 & 336 \\
\hline 寧夏中部および東南 & 7,686 & 3,262 & 3,289 & 1,136 \\
\hline 賀蘭山西麓山前平原 & 1,888 & 632 & 1,256 & \\
\hline 騰格里 [テンゲル $]$ 砂漠南縁 & 640 & & 640 & \\
\hline 弱水下游 & 3,480 & 344 & 2,848 & 288 \\
\hline 阿拉善 [アラゼン] 中部 & 2,600 & 392 & 2,208 & \\
\hline 河西廊下オアシス周辺 & 4,656 & 560 & 2,272 & 1,824 \\
\hline 柴達木 [ツァイダム] 盆地山前野原 & 4,400 & 1,136 & 1,824 & 1,440 \\
\hline 古爾班通古特 [グルバンテュンギュト] 砂漠周辺 & 6,248 & 952 & 5,296 & \\
\hline 塔克拉瑪干 [タクラマカン] 砂漠周辺 & 24,223 & 2,408 & 14,200 & 7,615 \\
\hline 合 計 & 176,442 & 80,960 & 60,677 & 34,805 \\
\hline
\end{tabular}


表-3 中国の潜在的な砂漠化土地の分布

\begin{tabular}{|c|c|}
\hline 地区 & 面積 $\left(\mathrm{km}^{2}\right)$ \\
\hline 呼倫貝爾 [ホロンバイル] & 4,260 \\
\hline 嫩江下流 & 1,501 \\
\hline 吉林西部 & 4,512 \\
\hline 科爾沁 [ホルチン] 草原 & 5,440 \\
\hline 西拉木倫 [シラムレン] 河上游 & 7,793 \\
\hline 河北坝上 & 5,536 \\
\hline 錫林郭勒 [シリンゴール] 草原 & 47,687 \\
\hline 烏蘭察布 [ウランチャブ] 市の後山 & 4,028 \\
\hline $\begin{array}{l}\text { 烏蘭察布 [ウランチャブ] 草原北部および } \\
\text { 狼山以北 }\end{array}$ & 19,200 \\
\hline 晋西北および陝北 & 5,840 \\
\hline 鄂爾多斯 [オルドス] 中西部 & 10,720 \\
\hline 寧夏東南部 & 2,560 \\
\hline 阿拉善 [アラゼン] 地区 & 17,865 \\
\hline 河西廊下 & 2,036 \\
\hline 柴達木 [ツァイダム] 盆地 & 3,520 \\
\hline 塔里木 [タリム] 盆地 & 12,690 \\
\hline 準噶爾 [ ジュンガル] 盆地 & 2,806 \\
\hline 合計 & 15,8000 \\
\hline
\end{tabular}

し, 光の席上, 自然条件と歴史的要因に近年の干ばつが加 わって，中国の砂漠化は「一部では改善されているが，全体 的には悪化」の傾向にあり，根本的な砂漠化の阻止はできて いないことを明らかにした。全国の砂漠化土地は，国土面積 の $18.2 \%$ にあたる約 $174 \mathrm{~km}^{2}$ であり，毎年 $3,436 \mathrm{~km}^{2}$ の ペースで砂漠化が進行していた。

以上より，20世紀の末と 21 世紀の初めの砂漠化はおもに “三つ増加，二つ減少，一つの転化”といった言葉て現され るような特徵を示している。増加とは(1)土壤の流失面積の増 加, (2)砂漠化土地の面積の増加 (年 $2,460 \mathrm{~km}^{2}$ ), (3)劣化し た草地の増加 (年 2 万 $\mathrm{km}^{2}$ ) を示している。減少とは(1)耕 地と, (2)湿潤地の減少である。光して転化とは林地が灌木林 や疏林,草地に変えられてしまったことを指している。

2002 年以降, 砂漠化の状況は大きく変化した。つまり， 全国で砂漠化を防止し，砂漠化土地を整備した面積は 1.9 万 $\mathrm{km}^{2}$ に達しており，全国で一年間に砂漠化する土地の面積を 超えている。現在, 砂漠化した土地の面積か海年減少しつつ ある省 (自治区) はすでに全体の 3 分の 2 に達しており， 重点省 (自治区) では生態環境が悪化する傾向は一応抑制さ れてきている。

例えば, 内蒙古自治区の砂漠化の拡大速度は, 1994 1999 年は $0.87 \%$ であったが, 現在は $0.25 \%$ になっている。 この数值は国際的に見ても決して異常に高いものではない。
新疆ウイグル自治区では, この 10 年間で砂漠化土地の拡大 速度が 50 \% 低下し，さらに毎年下降傾向にある。光の結 果, 各地で草花力甡い茂り, 野生動物も増え, 河川や湖の水 位も上がるなどの生態環境の好転の兆しが見えてきている。 寧夏回族自治区では数十年来の努力により, 砂漠化防止・整 備面積の累計が $4,000 \mathrm{~km}^{2}$ になった。しかも実施速度か砂漠 化土地の拡大速度を大幅に上回っているため, 砂漠化土地の 面積は $16.5 \mathrm{~km}^{2}$ から $12.5 \mathrm{~km}^{2}$ に減少した。河北省, 山西 省, 吉林省と陝西省の榆林市, 甘肃省の河西回廊, 新疆ウイ グル自治区の塔里木 [タリム] 川下流域などの重点砂漠化地 域では, 砂漠化の減少, 生態環境の明らかな改善力認められ るようになってきている。

\section{2 .3 砂嵐の発生}

砂漠化の進行に伴って砂嵐の発生頻度が高くなった。特に 20 世紀の後期に急激に増加した。中国北西地域での記録に よると, 1951 年から 1960 までの 10 年間に 5 回の砂嵐が発 生した。1961 年から 1970 年までの 10 年間には 8 回発生 し，1971 年から 1980 年までの 10 年間には 13 回発生した。 1981 年から 1990 年までの 10 年間には 14 回発生し, 1991 年から 2000 年まで 23 回であった。

1980 年頃から砂嵐の強度か増してきている。いくつか例 を挙げると，1979年 4 月から 6 月に塔里木 [タリム] 盆地 で 3 回砂嵐が発生し, 弚のうちの一つは尉犁県に 3 日間で 約 $25,600 \mathrm{t} / \mathrm{km}^{2}$ の砂塵をもたらした。1983 年 5 月には新彊 ウイグル自治区の石河子開墾区で砂嵐によって $167 \mathrm{~km}^{2}$ の 農地力被害を受け，約 300 万元余りの経济的損失を被った。 1986 年 5 月には新疆ウイグル自治区の和田県で $133 \mathrm{~km}^{2}$ の 農地が被害を受け，約 5,000 万元の損害であった。1993 年 5 月には新疆ウイグル自治区の東部と甘肃の河西回廊, 寧夏 回族自治区, 内蒙古自治区の西部できわめて強い砂嵐（砂塵 暴と呼引゙)が発生し，380 人の人と 12 万頭の家畜か死亡し， $3,367 \mathrm{~km}^{2}$ の農地が被害を受け，約 5.4 億元の経済的損失が もたらされた。1994 年 4 月には内蒙古自治区の西部と甘肃 の河西回廊北部の砂漠からの砂塵が吹き上げられ，北京の上 空に飛来した。1994 年 5 月には甘肃省の河西回廊で砂嵐が 発生し, 約 1,243 万 $\mathrm{t}$ の砂塵が積もつた。また 1995 年 11 月には山東省の 40 余りの県 (市) を砂嵐か襲い, 35 人か死 亡し， 121 人が行方不明， 320 人が負傷した。关の結果，10 億元余りの経済的損失を被った。1996 年 5 月にも甘肃省の 河西回廊て砂嵐力発生し, 大量の黄砂力榌来し, 人々は呼吸 困難に陥った。最も深刻な被害を被った酒泉での経済的損失 は 2 億元余りに達した。1996 年 4 月には内蒙古自治区の中 西部と寧夏回族自治区の西南部, 甘肃省の河西回廊で砂嵐が 発生し， $307 \mathrm{~km}^{2}$ の農地が被害を受け，11.09 万匹の家畜が 死亡し，約 8 億元の損害であった。この時の砂嵐は北京， 済南，南京，杭州などの広い地域にまて影響した。1996 年 4 月には新彊ウイグル自治区の北部と東部の吐魯蕃 [トル ファン]盆地で強風のために 6 人か死亡, 44 人か行方不明， 256 人が負傷した。1998 年 5 月にも新䮠維吾尔 [新䮠ウイ グル] 自治区の北部の阿拉山，塔城などの地域て瞬間風速が 
$32 \mathrm{~m} / \mathrm{s}$ に達した。1999 年 4 月には内蒙古自治区の呼和浩特 市, 通遼市の南部, 鄂爾多斯 [オルドス] 市で強風と砂嵐で 視程か著しく低下した。通遼市南部の瞬間風速は $16 \mathrm{~m} / \mathrm{s}$ に 達した ${ }^{712}$ 。

\section{3 砂漠化防止の活動および研究の歴史}

今から 2000 年ほど前の秦の始皇帝や漢代の初期から砂漠 化防止のためにさまざまな対策力講じられてきている。しか し, 大規模な砂漠化防止の活動出研究力゙行われ始めたのは主 に最近 50 年ほどのことである。光の中国の砂漠化防止の歴 史は次のように大きくに 4 期に分けることができる。

第 1 期 : 新生中国が成立する以前 (19 世紀から 1940 年代) 1844 年に格龍というフランスの宣教師が中国の砂漠を調 査し，1857 年には鄂爾多斯 [オルドス] の自然についての 論文か発表された。弚の後, ロシア, ベルギー, スウェーデ ン,イギリス,アメリカ, ドイツ, 日本などの研究者や旅行 者か砂漠を調査や探検をした。中国国内では 1926 年から馮 景蘭, 陳世燦, 袁複礼, 冷亮などの研究者か砂漠に関する論 文を発表した ${ }^{10)}$ 。

第 2 期 : 新生中国の成立から文化大革命まで (1950 年代 から 1960 年代)

1950 年に河北省の石家莊に冀西砂荒漠造林局が創立され， 陝西省の榆林市に陝北防砂林場が作られた。この時期に河北 省と山東省の東部から西北部の 2.88 万 $\mathrm{km}^{2}$ の土地に大規模 な防風林が造成され，1958 年までに 0.67 万 $\mathrm{km}^{2}$ の人工林が 完成した。1956 年に中国科学院は寧夏回族自治区の中衛市 に砂坡頭試験所を創設し，中国林業科学研究院は榆林市に紅 石劮試験所を設けた。1958 年と 1959 年に中国政府は内蒙古 自治区の呼和浩特市と新疆ウイグル自治区の烏魯木斉 [ウル ムチ] 市において, 全国砂漠防止大会を二年連続して開催し た。1959 年から 1961 年にかけて, 中国科学院は中国の大き な砂漠を調査した。さらに，内蒙古自治区および西北各省に 六つの砂漠研究所を設け, 22 箇所の研究組合が作られ, 全 国に砂漠化防止のネットワークを形成された。1960 年には 内蒙古林学院に砂漠化防止の専門課程が設けられた。1970 年頃, 国家林業部力陝西省の檢林地域で大面積の空中散布試 験を行い, 成功した。1978 年から東北, 華北, 西北防風林 のプロジェクトが始まった。この時期から砂漠化の問題が注 目されるようになり，環境問題として重要視されるように なった。

第 3 期 : 文化大革命から 20 世紀末まで (1980 年代から 1990 年代)

80 年代の初め, 蘭州砂漠研究所の朱震達, 劉恕などが北 部地域の砂漠化についての研究を始めた。90 年代になると 中国政府は砂漠化を最重要の課題の一つとして取り上げるよ うになり，1991 年，1993 年に第三，第四回全国砂漠化防止 大会か開かれた。また，国務院に砂漠化防止事務室を置か れ，全国的な砂漠防止活動はこの時から始まった。1994 年 に「砂漠化対処条約」を批准した。1994 年から1996 年にか けて国家林業部は砂漠化の現状について調査を行い，中国の 砂漠化の現状か明らかになった。2000 年に「砂漠化防止法」
か湤行された。

第 4 期 : 21 世紀に入ってから

21 世紀に入ってから中国政府は「中国 21 世紀議程」「「中 国環境保護 21 世紀議程」,「中国 21 世紀議程林業行動計 画」，「全国生態環境規律」などを策定し，光の上に「森林法」，

「草原法」,「水土保持法」,「環境保護法」、水法」「㘳地管 理法」などの砂漠化防止と関連する法律を制定した。こうし た計画の実施と制度の整備によって木材生産を抑制し，環境 保全に重点を置いた森林管理を進めようとしている (生態建 設)。目標は 2010 年までに森林被覆率を $19 \%$ 以上にし，河 川流域の土㙥流失と砂漠化を防止し, 全国規模て環境の悪化 をくい止め, 森林管理の合理化を图ろうとしている。2020 年までに森林被覆率を $23 \%$ 以上とし, 重点地域の環境問題 を解決し，全国の生態改善と木材生産の充実を目指す。 2050 年までに森林被覆率を $26 \%$ 以上にすることで麗しい国 土を実現し，良好で充実した森林生態体系を建設するととも に，必要十分な木材生産を可能とすることを最終目標とする ものである゙”。

\section{2. 新生中国の砂漠化防止に関する実績}

新生中国は建国以来砂漠化の防止に努めている。光のため に全国の砂漠化土地の現状を捉え，砂嵐の発生をモニタリン グし, 砂漠化の進展による災害を防止するための全国ネット ワークを形成した。第九次五年計画では 23 万 $\mathrm{km}^{2}$ の水源地 が保護され，20万 $\mathrm{km}^{2}$ の防風林が造成された。砂漠化の防 止は経済の発展に欠かせないものであり，いろいろな国家プ ロジェクトを実施している。中でも「緑の長城」といわれる “三北”(東北，華北，西北を三北という) 防風林プロジェ クトや防風林ネットワーク, 砂漠化防止プロジェクト, 北 京・天津風砂源プロジェクト，退耕還林還草プロジェクトな どがある。砂漠化防止のプロジェクトでは主に植生の回復と 保護が注目され，水分収支を考量した近自然林の造成が進ん でいる。

2.1 三北 (東北, 華北, 西北) 防風林プロジェク卜

三北 (東北，華北，西北) 防風林プロジェクト ${ }^{13}$ は生態系 修復のための重点プロジェクトとして 1978 年 11 月に始ま り，2050 年までに 37.7 万 $\mathrm{km}^{2}$ の造林を行う予定である。プ ロジェクトの対象地域は中国の西北 , 華北 , 東北地方の 13 省（自治区，直轄市を含む）の 551 県（旗，市，区) であ り，実施する地域の総面積は 406.9 万 $\mathrm{km}^{2}$ に達し，およ光 国土の $42.4 \%$ にあたる。

プロジェクトの目標として , 対象地域の森林面積を 1977 年の 23.14 万 $\mathrm{km}^{2}$ から 2050 年には 60.84 万 $\mathrm{km}^{2}$ とし，森林 被覆率は 1977 年の $5.0 \%$ が 2050 年には $15.0 \%$ になる予定 である。弚の結果，木材蓄積量は 1977 年の 7.2 億 $\mathrm{m}^{3}$ に対 して，2050 年には 42.7 億 $\mathrm{m}^{3}$ に増加し，林業収入は 1977 年の 9 億元から 2050 年には 210 億元に増加する予定であ る。従って，2050 年にこのプロジェクトが全て完了すると， 東北，華北，西北地方に防風林のネットワークを形成され， 風砂の危害や土㙥流失, 砂漠化などはすべて抑制されると考 
えられている。プロジェクトを実施した地域の環境は改善さ れ, 人々の生活環境も向上することになる。プロジェクトの 期間は 73 年で, 弚の中は大きく三つの段階に分けられる。 第一段階は 1978 年から 2000 年までである (第一期 : 1978 ～1985 年, 第二期：1986 1995 年, 第三期：1996 2000 年)。第二段階は 2001 年から 2020 年までの 20 年間である (第一期 : 2001 2010 年, 第二期 : 2011 2020 年)。第三 段階は 2021 年から 2050 年までの 30 年間である (第一期 : 2021 2030 年, 第二期: 2031 2040 年, 第三期 : 2041〜 2050 年)。

第一段階の第一期で 7.04 万 $\mathrm{km}^{2}$ の造林を行った。弚の内 訳は人工造林が 6.1 万 $\mathrm{km}^{2}$, 封山育林が 0.8 万 $\mathrm{km}^{2}$, 空中散 布造林が 0.1 万 $\mathrm{km}^{2}$ ，緑化用の植林が 136,114 万株であっ た。第二期の造林面積は 11.3 万 $\mathrm{km}^{2}$ (人工造林が 0.8 万 $\mathrm{km}^{2}$, 封山育林が 3.2 万 $\mathrm{km}^{2}$, 空中散布造林が 0.5 万 $\mathrm{km}^{2}$, 緑化用の植林が 26.3 億株), 第三期は 4.2 万 $\mathrm{km}^{2}$ (人工造林 は 3.6 万 $\mathrm{km}^{2}$ ，空中散布造林は 0.6 万 $\mathrm{km}^{2}$ ) であった。

第一段階で 6.76 万 $\mathrm{km}^{2}$ の造林か完了し, 砂漠化が防止さ れた土地は約 4 万 $\mathrm{km}^{2}$, 実際に生産力が回復した農地は 0.67 万 $\mathrm{km}^{2}$ に上り，およ光 $20 \%$ の砂漠化した土地か整備さ れた。砂漠化し, 土壌がアルカリ性となってしまった 10 万 $\mathrm{km}^{2}$ の草原が生産力を回復し, 牧草の生産量は以前の $20 \%$ 以上増加した。毛烏素砂地, 科爾沁 [ホルチン] 砂地の植被 率は 1977 年の $7 \%$ と $10.9 \%$ から 2000 年には光れ光れ 20.4 \%と $29.1 \%$ に増加した。

\section{2 砂漠化防止プロジェクト}

1991 年から始まった砂漠化防止プロジェクトは 27 省 (自 治区，市) の 598 県を対象とし，国土面積の $27.5 \%$ を占め ている。1999 年の段階で, 植林面積は 80 万 $\mathrm{km}^{2}$ にのぼり， 砂漠化の進行を食い止める効果を発揮している。

プロジェクトの効果として陝西省榆林の例を挙げると，植 被率は 50 年代の $1.8 \%$ から $38.9 \%$ に高まった。砂嵐の日数 は 50 年代より 30 日減少した。また, 砂丘の移動速度は年 平均 $5 \sim 7 \mathrm{~m}$ から $1.68 \mathrm{~m}$ 以下に減少し, 砂丘から川へ流出 する土砂量は以前の半分になった。また，内蒙古自治区の赤 峰の植被率は 1950 年は $5 \%$ であったものが, 現在は $21.2 \%$ までに高まり，食糧の生産量は 3 億 $\mathrm{kg}$ から 12.5 億 $\mathrm{kg} に$ に増 加した。

2.3 北京・天津風砂源プロジェクト

国務院は 2002 年に「京・津風砂源プロジェクト (2001〜 2010 年)」を策定した。このプロジェクトは樣々な措置 (放 牧の禁止, 生態移民, 封山育林, 草本植物の種子の空中散 布, 人工造林, 育草, 退耕還林, 水土流出地の総合工事) に よって, 北京と天津地域の黄砂や砂嵐を防止し, 環境を改善 させるものである。

このプロジェクトは北京市, 天津市, 河北省, 内蒙古自治 区, 山西地域の五省 (区，市) を対象地域としている (総面 積は約 45.8 万 $\mathrm{km}^{2}$ )。このプロジェクトの総投資額は 558 億 元である。草原の植生を回復させるための作業は 2000 年か ら 2006 年までに 8.03 万 $\mathrm{km}^{2}$ ほどで実施し，この計画の
$99.5 \%$ が完了した。光のほか, 2007 年にも $400 \mathrm{~km}^{2}$ の植生 の回復に取り組んだ。プロジェクトの実施によって，草原の 環境が回復し，リモートセンシングの測定結果によると，錫 林郭勒 [シリンゴール] 草原の植被率は実施前より $20 \%$ か ら $30 \%$ ほど増加し, 草の生産量も 30〜60\% ほど増加した。 2.4 退耕還林還草プロジェクト

西部大開発プロジェクトを実施するにあたって退耕還林事 業を西部大開発プロジェクトの一つに加えた。2000 年には 13 省で退耕還林還草を実施した。退耕還林還草政策は 2002 年にまとめられた「中国六大林業重点工程」においても重要 な緑化政策として位置にづけられている。

退耕還林還草プロジェクトは農耕に適さない開墾地て耕作 を中止し (退耕)，森林を造成する (還林) ものである。無 理な耕作をやめることて環境の劣化を食い止め, 元の植生で ある森林や草地を回復させることで土地の潜在的な生産力を 取り戻关うとするものである。従って, 対象となる土地は土 砂流失が起こりやすい急傾斜地や砂漠化しやすい半乾燥地に 開かれた耕地やすでに放棄された荒廃地である。こうした土

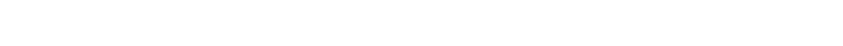
や草を植栽し，森林や草地に回復させていく ${ }^{15)}$ 。

退耕還林還草政策はどこもかしこも緑化しようとするもの ではない。草原の荒廃や過牧化, 農地化にブレーキをかける 効果力浗められているため, 対象地域力限定されている。

国土保全と農民の生活安定，農村振興を同時に達成するこ とを目的として, 自然環境の改善, 退耕還林の当事者となる 農民の利益の確保，農村産業の振興と効率化を掲げている。

\section{3. 砂漠化防止のモデル}

1950 年代から中国は大規模な砂漠の研究を始めている。 兴の結果, 第 6 次〜第 9 次の 5 力年計画で砂漠化のモニタ リングと対策技術の開発を始めている。光の中でも榆林の総 合開発モデルは道路沿いの飛砂防止に成功した。乥の後も 「経済生物圈」などさまざまな整備のモデルが各地に実施さ れている。光のいくつかは次のようなものがある。

\section{1 道路沿いの防砂}

中国は面積が広く，道路や鉄道か砂漠や砂地を貫いてい る。砂漠を縦断する道路や鉄道は常に砂嵐や流動砂丘によっ て埋められてしまう危険にさらされている。乥こで, 鉄道や 道路の両側には砂の飛来を抑えるためのいろいろの措置をな されている。特に新疆ウイグル自治区や内蒙古自治区は，砂 漠や砂地の面積が広く, 道路の防砂が最も重要な課題であっ た。

包 (頭) から蘭 (州) までの包蘭鉄道の蘭州に近い砂坡頭 では西から進んできた騰格里 [トンゴリ] 砂漠が黄河に落ち 込んでいる。この砂漠を横切って鉄道を施設しなければなら ず, 1956 年から中国科学院は多くの研究組織を糾合し, 鉄 道沿線の防砂についての共同研究を行った。この地域の年降 水量は僅か $186 \mathrm{~mm}$, 砂の含水率は $2 \%$ 程度しかなく, 強風 が吹く日数は 200 日に達し, 最大風力は 11 級の記録もあ り，植被率は $1 \%$ しかなかった。流砂の害を防ぐために砂 
障で砂丘を固定すると同時に，樣々な防風林システムを造成 した。弚れから 50 年が経ち, 自然環境が大きくに改善さ れ，生物多樣性の高い生態系が回復している。ここで成功し た技術としで 麦草方格”と耐乾性のある植生の造成が挙げ られる6 。まず, 方形, 菱形, 三角形の草方格が試され，1 $\mathrm{m} \times 1 \mathrm{~m}$ の方形の麦わらを使った草方格の砂障が最も効果的 であることか認められた。草方格の中には高木や草本ではな く耐乾性のある潅木を選んで植栽した。全体としては鉄道線 路に最も近いところは卵大の石を敷き詰めた防火带とし，光 の外側に灌水施設を伴った潅木林帯を造成した。さらに光の 外側には草方格によって造成した緑地帯と流砂を止める草地 を造成した。植生帯の幅は全部で風上側は $300 \mathrm{~m}$ ，風下側は $200 \mathrm{~m}$ とした。

同じ包蘭鉄道の烏海段は砂坡頭より降水量が少なく (年平 均 $150 \mathrm{~mm})$, 草方格による緑地帯造成が困難であった。光 こで, 1980 年代に内蒙古林学院と中国鉄道西北研究所, 呼 和浩特鉄道局か協力して，アスファルトによる流砂固定を行 い, 1990 年代に灌水システムを導入することで緑地帯の造 成に成功した。

道路が流砂に埋まるのを防止することはきわめて重要なこ とであり，庫布斉 [クブチ] 砂漠の中を走る幹線道路や塔克 拉瑪干 [タクラマカン] 砂漠の油田道路などで道路沿いの防 砂技術が開発されている。2005 年に開通した内蒙古自治区 の海拉爾から陝西省の蘇家河畔までの幹線道路（総延長 $2,515 \mathrm{~km})$ の約 $200 \mathrm{~km}$ の部分は渾善達克 [フンシャンダク] 砂地を貫通している。この道路の両側はこれまでの経験を利 用して，柵や草方格などの砂障によって砂の移動を阻止した 上で，耐乾性の植物を植栽することで流砂の来襲を防止して いる。

\section{2 防風林}

中国での防風のための施設 (防風林, 防風垣, 防風林網, 草方格)についての文献は多く，弚の防風や気象改良の効果， あるいは作物収量への影響などについて詳しい解説力行われ ている ${ }^{14)}$ 。防風林は光の目的によって形態はさまざまなもの となる。中国て防風林が本格的に造成され始めたのは新生中 国の建国後であり，中国の東北地方西部や内蒙古自治区の東 部で, ソビエト連邦 (現ロシア) の指導を受けながら, 農地 や草原を取り囲むように大規模な防風林が造成された うした地方では晚春から初夏にかけて強い熱風か瀕発して, 農作物に大きな被害を与えていた。また, 中国の農地の 1 枚の面積は広いため, 大規模な防風林の造成が進められた。 兴の後に西北地方や華北地方の草原, 新疆ウイグル自治区の オアシスでは地域の実情に応じて $200 \mathrm{~m} \times 200 \mathrm{~m}$ の“狭い林 帯と小網格 (小さなネットワーク)” と呼ばれる防風林ネッ トワークの造成が進められた。兰うしたきめ細かな農田防風 林は土地資源を十分に利用しながら，自然災害を抑えること ができるので, 経済的にも大きな効果がある。

3.3 空中散布による植生の造成

1980 年代以降, 砂漠や砂漠化した土地で種子の空中散布 による大規模な緑化が進められており ${ }^{8)}$ ，これからも続けら
れていくものと考えられる。種子の空中散布による緑化の成 否は, 対象とする場所や播種する植物種の種類の選択，散布 の時期 , 乥して播種する種子の量によって決まる。緑化のた めの労働力を確保するのか困難な人口密度の低い地域で空中 播種は効果的である。播種する植物は一つではなく，いくつ の種類の種子を混ぜて散布することで，定着率が向上する。 播種する地域は砂漠化が進み, 乾燥しているので, 散布前に 種子を保水剂で包むといった処理を行うことで発芽率が向上 する。種子の発芽・定着には降雨が次せないので, 播種後 に十分な降雨か期待できる時期を選ばなければならない。播 種量は種子の質や播種時の風速，砂の移動の程度，動物によ る被害の強さなどによって決まる。

3.4 砂漠における生物経済圈

砂漠化土地の中で農業生産を持続的に進めていくために は, 土地の利用を合理的にしていかなければならない。光の ための考え方の一つとして「生物経済圏」というものがある。 生物経済圏は中心区と保護区で構成される。全体の面積は $0.04 \sim 0.1 \mathrm{~km}^{2}$ で, 新たに構筑するとすれば $3 \sim 5$ 年で完成す る。たとえば毛烏素砂地の伊金霍洛旗では砂丘と丘間低地， および丘陵地の三つの異なる立地の土地がモザイク状に分布 している。光れらを相互に組織化して生物経済圈を構築する ならば，丘間低地を中心区とする (第一圈)。弚こは水分条 件のよい低地であるため, 高収量の作物や牧草, 経済植物な どを栽培し, 経済収入の向上を目指す。光の外側の砂丘地や 緩やかな傾斜面 (第二圏) では天水によって牧草などを栽培 する。最外縁部の半固定砂丘や流動砂丘 (第三圈) には防風 林を建設する。科爾沁 [カルチン] 砂漠の中の科爾沁左翼後 旗では, いくつかの世帯が集まって 0.04 0.07 km² の広さ の生物経済圏を設け手いる。光こでは周辺にはさまざまな形 態の防風林 (潅木および高木防風林) を建設し, 中心区は高 収量の作物や牧草, 経済植物, 果樹などを栽培している。

3.5 樣々な方法を総合した砂漠化防止の取り組み

砂漠や砂漠化土地は降水量が少ないので, 砂漠化防止のた めの緑化を進めるためには地域の水収支についての慎重な配 慮が欠かせない。どのような緑化植物を利用するかを決める 際には水分の供給量と消費量の長期的な予測をしておかなけ ればならない。砂漠化土地は環境か沙化してしまっているの で, 土地の修復のためには, 長期的な展望を持って,さまざ まな対策技術を総合的に組み合わせて進めなければならな い。たとえば，裸地化した放牧地では，緑化植栽の前に土地 利用を禁止するための封鎖が必要であり，弚のための住民相 互のコンセンサスの形成が欠かせない。土猿の流失が激しい 地域では耕作や放牧を禁止するとともに，土木工事による立 地の整備が欠かせない。

\section{引用文献}

1）曹新孙主编（1993）农田防护林学, 中国林业出版社, 北京.

2）李并成（1986）唐代敦煌绿洲水系考, 中国史研究, 1:159-168.

3）李并成（1993）残存在民勤县西沙窝中的古代遗址, 中国沙 漠, $10(2): 34-42$. 
4）李并成（1996）河西走廊历史時期气候干湿状况变迁考略, 西北师范大学学报 (自然科学版), 32(4):56-61.

5) 武弘麟（1985）科尔沁沙地沙漠化初探, 北京大学硕士学位 论文, pp.21-24.

6）于云江 - 林庆功 - 石庆辉 - 刘家琼 (2002) 包兰铁路沙 坡头段人工植被区生境与植被变化研究, 生态学报, 22 (3):433-439.

7）赵承·李佳路（2000）近年我国出现的大风和沙尘暴, 新华 通讯社北京分社, 4 月 6 日.

8）中国飞播造林四十年编委会（1998）中国飞播造林四十年， 中国林业出版社，北京.

9）周生贤（2005）当前林业的形势与任务, 全国林业厅局长会
议上的讲话，国家林业局网，4月 1 日 .

10）朱震达 - 吴正 (1980) 中国沙漠概论, 科学出版社, 北京.

11) 朱震达·刘恕 (1989) 中国沙漠化及其治理, 科学出版社, 北京.

12）近 50 年我国的强沙尘暴，北京晚报，2000 年 3 月 29 日.

13） 1981 年国家林业局三北防护林建设局（2000）建设中的三 北防护林体系工程 .

14）真木太一（2005）乾燥地の防風施設による気象改良特性, 地球, 10 (1).

15）吉川賢（2004）乾燥地の自然と緑化, 吉川 賢・山中 典和 · 大手信人編著, 乾燥地での緑化技術, 共立出版, pp.174-210.

(2008.4.18. 受理) 